\title{
Typologia grup interesu artykułujących postulaty Kościoła katolickiego w Polsce
}

Streszczenie: Celem artykułu jest dokonanie klasyfikacji grup interesu artykułujących postulaty Kościoła katolickiego w Polsce. W związku z tym zdefiniowano Kościół w ujęciu politologicznym, określono formy oddziaływania Kościoła na system polityczny, określono pojęcie grup interesu w odniesieniu do analizowanej problematyki, następnie w oparciu o określone kryteria dokonano ich typizacji. Zaproponowana typologia może stanowić punkt wyjścia do dalszych badań w tym zakresie.

Słowa kluczowe: Kościół katolicki w Polsce, system polityczny, grupy interesu

\section{Wstęp}

$\mathbf{P}$ o przemianach ustrojowych 1989 r. Kościół katolicki odgrywał i pełni nadal istotną rolę w życiu publicznym Polski. Kościół, podejmując określone kwestie polityczne i społeczne, stawał się bezpośrednim lub pośrednim uczestnikiem procesu politycznego (Lipiński, 2016, s. 52-55). Kościół włączył się w sferę polityki i proces stanowienia prawa, legitymizując określone partie i ugrupowania oraz wspierając projekty ustaw. Legitymizacja podmiotów polityki wyrażała się w spotkaniach hierarchów katolickich z ich liderami, pośrednim wskazaniem pozytywnym w wyborach. Kościół nie udzielił jednoznacznego poparcia ściśle określonej partii, jednakże w pierwszej połowie lat 90. XX w. niektórzy biskupi wspierali działania integracyjne stronnictw, ugrupowań i środowisk prawicowych. Działania te ustały generalnie od drugiej połowy lat 90. Kościół włączył się również bezpośrednio w implementację swoich kluczowych postulatów - nadanie stosunkom wyznaniowym określonego kształtu w ustawie zasadniczej, podpisanie i ratyfikację konkordatu, wprowadzenie nauki religii w szkołach, zapisów o wartościach chrześcijańskich w ustawie medialnej, ustawodawstwa antyaborcyjnego, zakazu zapłodnienia in vitro i niezgody na legalizację związków partnerskich (Kowalczyk, 2016, s. 98-99). Kościół instytucjonalny wyrażał swoje postulaty również za pośrednictwem wspierających go grup interesu.

Zasadniczym celem artykułu jest dokonanie klasyfikacji grup interesu artykułujących postulaty Kościoła katolickiego w Polsce. W celu realizacji niniejszego zadnia: zdefiniowano Kościół w ujęciu politologicznym, określono formy oddziaływania Kościoła na system polityczny, określono pojęcie grup interesu w odniesieniu do analizowanej problematyki, następnie w oparciu o określone kryteria dokonano ich typizacji. Kluczowe znaczenie dla tak ujętego problemu badawczego miała metoda analizy systemowej i studia przypadków.

Przez pojęcie Kościół należy tu rozumieć „Kościół hierarchiczny”, nie zaś wspólnotę wiernych. Termin ten jest tożsamy z katolicką hierarchią kościelną, tj. biskupami, 
w szczególności diecezjalnymi. Przez pojęcie „postulaty Kościoła” należy natomiast rozumieć określone kwestie problemowe podjęte w nauczaniu społecznym Kościoła (NSK) w Polsce. Poszczególni biskupi współkształtują NSK poprzez wydawanie listów pasterskich, głoszenie homilii, udzielanie wywiadów. Na terytorium RP biskupi skupiają się w ramach Konferencji Episkopatu Polski (KEP) (Delong, 2016, s. 17-43).

\section{Kościól jako podmiot oddziałujący na system polityczny}

Kościół jest definiowany w różnorodny sposób przez reprezentantów nauk o polityce jak: wspólnota - organizacja religijna, grupa interesów, aktor polityczny i religijny (Kowalczyk, 2015, s. 15-21). W niniejszym artykule w ujęciu stricte politologicznym Kościół jest definiowany jako podmiot znajdujący się w otoczeniu systemu politycznego i oddziałujący na ten system. Podmiotowość w tym kontekście oznacza możliwość realizowania swoich celów, zamierzeń i działań, w tym sensie Kościół jest zinstytucjonalizowanym podmiotem sprawczym. Jest bowiem strukturą zorganizowana, zhierarchizowaną. Członkowie podmiotu sprawczego przekazują część swoich atrybutów na poziom ugrupowania, w skład którego wchodzą. Ta zależność - delegacja uprawnień - wyraża się lojalnością i podporządkowaniem decyzjom podejmowanym na poziomie owego ugrupowania (Wnuk-Lipiński 2005, s. 89). Na poziomie Kościoła powszechnego kluczowe decyzje podejmowane są przez papieża, w zespole Kościołów partykularnych (w danym państwie) przez Episkopat i jego prezydium, w Kościele partykularnym przez biskupa - rządcę diecezji. Pojęcie systemu politycznego jest określane jako ogół instytucji politycznych, za pośrednictwem których podejmowane są decyzje polityczne, oraz generalnych norm i zasad regulujących stosunki między nimi. W ujęciu instytucjonalnym pojęcie instytucji politycznych odnosi się do zorganizowanych aktorów politycznych, przede wszystkim organów państwowych i partii politycznych. W ujęciu neoinstytucjonalnym instytucje polityczne są określane jako reguły gry i struktury, ucieleśniające pewne wartości i układ sił oraz determinujące odpowiednie zachowania jednostek w określonych kontekstach (March, Olsen, 1989, s. 17). W celu urzeczywistnienia wartości i artykulacji interesów Kościół wywiera zatem wpływ na partie polityczne, aby oddziaływały na proces legislacyjny i rządowy proces decyzyjny, oraz bezpośrednio na poszczególne organy władzy - parlament, rząd, sądy i trybunały. Kościół wywiera również wpływ na formalne i nieformalne reguły funkcjonowania systemu politycznego, a tym samym na zachowania zbiorowych i indywidualnych aktorów politycznych. Z perspektywy neoinstytucjonalizmu normatywnego można zatem przeprowadzić analizę oddziaływania Kościoła na system polityczny w ujęciu dynamicznym. Rozpatrując oddziaływanie Kościoła na system polityczny należy wyróżnić kryterium podmiotowe, przedmiotowe, formy oddziaływania i zamierzonego celu (por. Hierlemann, 2005; Enyedi, 2003, s. 218-232).

Podmiotem oddziaływania Kościoła krajowego są organy władzy państwowej oraz partie, grupy interesów, media i społeczeństwo. Kryterium przedmiotowe pozwala na wyodrębnienie następujących kwestii problemowych, podejmowanych przez Kościoły krajowe: sfera bieżącej polityki (stanowiska wobec wyborów, referendów); preferowany model stosunków wyznaniowych (zwarty w przepisach konstytucyjnych, konkordacie, 
PP 2 '17 Typologia grup interesu artykułujących postulaty Kościoła katolickiego...

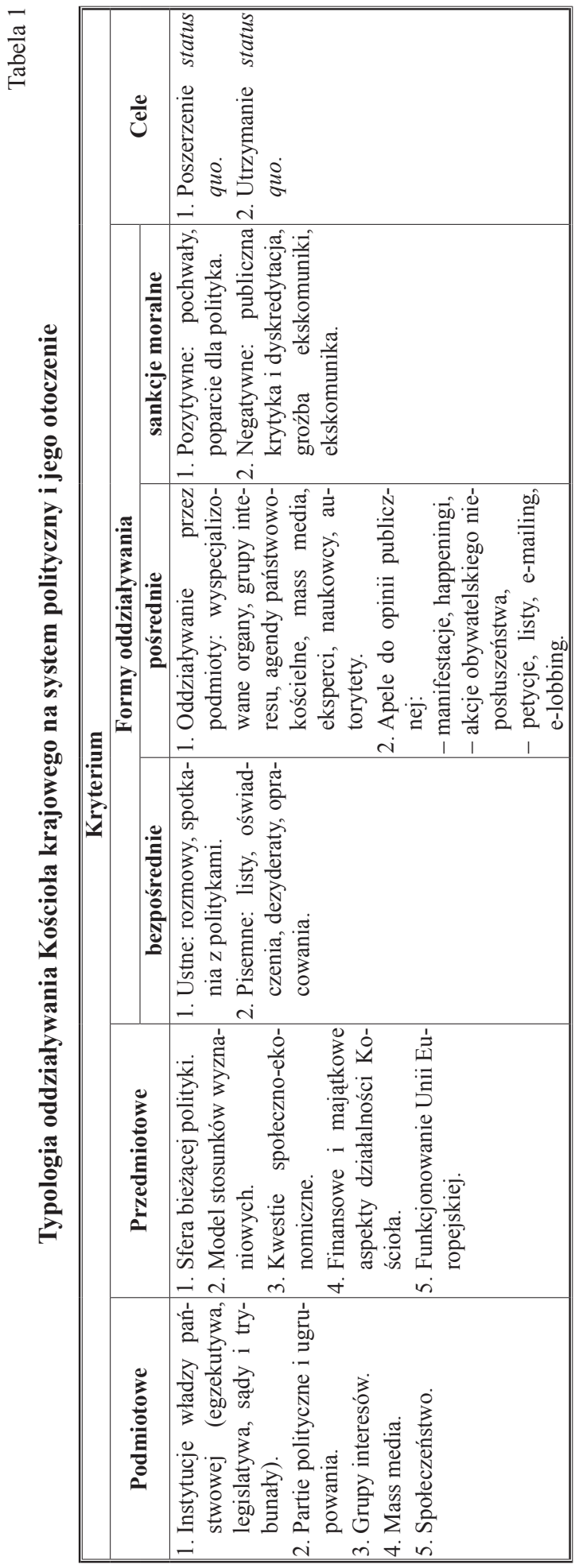


ustawach i rozporządzeniach); kwestie społeczno-ekonomiczne (dezyderaty dotyczące polityki społecznej); finansowe i majątkowe aspekty działalności Kościoła (subwencjonowanie Kościoła ze środków państwowych, podatek kościelny, kwestie własności kościelnej); funkcjonowanie Unii Europejskiej (respektowanie wartości chrześcijańskich w ustawodawstwie unijnym). Po 1989 r. Kościół katolicki w Polsce występował z precyzyjnymi postulatami w odniesieniu do wszystkich wyżej wymienionych kwestii problemowych (Delong, 2015, s. 44-343).

Formy oddziaływania Kościoła na system polityczny i podmioty znajdujące się w jego otoczeniu są często zbliżone do metod i technik właściwych dla lobbingu. Celem tego oddziaływania jest artykulacja własnych wartości i interesów oraz przekonanie decydentów politycznych do określonych rozwiązań prawnych i administracyjnych. Można wyróżnić dwie formy oddziaływania Kościoła z uwagi na kryterium sposobu artykulacji wartości i interesów: 1) bezpośrednie i 2) pośrednie. W pierwszym przypadku biskupi bezpośrednio oddziałują na decydentów, w drugim zaś korzystają z pośrednictwa innych podmiotów. W ramach oddziaływania bezpośredniego można wyróżnić formy ustne i pisemne. Do formy ustnej należą: oficjalne i zakulisowe rozmowy, spotkania, konferencje, sympozja z politykami. Natomiast do formy pisanej można zaliczyć: listy, oświadczenia, dezyderaty, opracowania kierowane do decydentów politycznych. Kościół instytucjonalny dąży do realizacji swoich celów i interesów za pośrednictwem następujących podmiotów: swoich wyspecjalizowanych organów, grup interesów, mass mediów, wspólnych organów kościelno-państwowych, ekspertów, naukowców, mobilizacji opinii publicznej. Szczególną formą oddziaływania Kościoła instytucjonalnego na system polityczny, wykraczającą poza klasyczne metody lobbingu, są sankcje moralne. Mobilizują i skłaniają one indywidualnych i zbiorowych aktorów politycznych do działań zgodnych z wartościami i interesami Kościoła. Sankcje moralne są reakcjami Kościoła na zachowania swoich członków w sytuacjach społecznie ważnych. Sankcje moralne mogą mieć charakter pozytywny - wzmacniający, są to: pochwały, wyrazy publicznego uznania czy wsparcia dla określonego aktora politycznego, np. opowiadającego się za opcją pro-life w parlamencie. Repertuar sankcji negatywnych jest zróżnicowany: od negatywnej oceny poczynań polityka, jego potępienia, poprzez zerwanie z nim kontaktów, po groźbę ekskomuniki.

$\mathrm{Z}$ uwagi na zamierzone cele można przyjać podział form wpływu Kościoła na strategie ofensywne i defensywne. Strategie ofensywne mają na celu rozszerzenie zakresu obowiązującego ustawodawstwa w sposób zgodny z wartościami i interesami Kościoła (np. poszerzenie zakresu obwiązywania ustawy antyaborcyjnej). Strategie defensywne zmierzają do utrzymania status quo (np. działania przeciw liberalizacji ustawy antyaborcyjnej).

\section{„Prokościelne” grupy interesu}

Jak wspomniano, Kościół katolicki w Polsce oddziałuje na system polityczny i jego otoczenie za pośrednictwem grup interesu. Pojęcie ,prokościelnych” grup interesu, czyli artykułujących jego postulaty wymaga sprecyzowania. Termin ten jest węższy niż religijne grupy interesów czy podmioty polityczne (aktorzy polityczni) odwołujące się do 
wartości. Według Caelesty Braun-Poppelaars i Marcela Hannegraaff’a pojęcie „religijne grupy interesu" (religious interest groups) odnosi się do różnych form organizacyjnych, ich istotą jest współdziałanie z decydentami, reprezentują oni zbiór norm i wartości narzuconych przez nadprzyrodzone i bezosobowe siły, których istnienie jest traktowane jako aksjomat. (Braun-Poppelaars, Hannegraaff, 2011, s. 133). Maciej Potz definiuje organizacje religijne jako unikalnych aktorów politycznych opartych na wartościach (value-based political actors). (Potz, 2016, s. 101).

Konrad Oświecimski określa grupę interesu jako zrzeszenie jednostek bądź organizacji lub instytucję będąca podmiotem władzy publicznej, która na podstawie wewnętrznie podzielanych wartości stara się aktywnie wpływać na kształtowanie polityki publicznej, lecz nie dąży do formalnego sprawowania władzy (Oświecimski, 2012, s. 43-44). W tym kontekście można stwierdzić, że grupy interesu artykułujące postulaty Kościoła to zrzeszenia jednostek, organizacji lub instytucji. „Prokościelne” grupy interesu są naturalnymi sojusznikami Kościoła w działaniach na rzecz implementacji w ustawodawstwo państwowe preferowanych przez niego norm i wartości, wynikających NSK ${ }^{1}$. W tym sensie grupy te zajmują się rzecznictwem religijnym (religous advocacy) ${ }^{2}$, prowadzą lobbing na rzecz Kościoła katolickiego (Kuntson, 2015, s. 3585-3589). Dodajmy, że w USA funkcjonuje termin religijne organizacje rzecznicze (doradcze) - religious advocacy organizations, odnoszący się do grup interesu artykułujących postulaty różnych kościołów i związków wyznaniowych, odznaczających się zróżnicowaną strukturą i metodami działania (Herzke, 2012, s. 15).

\section{Typologia „prokościelnych” grup interesu}

Rozpatrywane „prokościelne” grupy interesu w Polsce charakteryzują się zróżnicowaną strukturą organizacyjną i stopniem formalizacji; składem członkowskim; zasięgiem terytorialnym; realizowanymi celami oraz typem zależności od Kościoła instytucjonalnego. W związku z powyższym można wyodrębnić określone kryteria typologii tych podmiotów, odpowiadające polskim realiom (por. Herzke, 2012, s. 34$36)$.

I. Kryterium organizacyjne-formalne.

1) stowarzyszenia;

2) fundacje;

3) federacje organizacji pozarządowych;

4) instytucje;

5) związki zawodowe;

6) podmioty niesformalizowane:

a) katolickie ruchy religijne,

b) grupy wiernych.

${ }^{1}$ Należy jednocześnie podkreślić, iż gros organizacji pozarządowych i grup nieformalnych związanych instytucjonalnie lub programowo z Kościołem katolickim w Polsce skupia się na realizacji zadań formacyjnych, oświatowo-wychowawczych, charytatywno-opiekuńczych; nie zaś na artykułowaniu jego postulatów w sferze publicznej.

2 Termin religius advocacy można określić jako religijne rzecznictwo, religijną adwokaturę, obronę. 
W myśl ustawy stowarzyszenia, to dobrowolne, samorządne, trwałe zrzeszenia o celach niezarobkowych (Ustawa z dnia 7 kwietnia 1989 r..., art. 2, ust. 1). Ustawodawca wyróżnił stowarzyszenia zarejestrowane (posiadające osobowość prawną, którą uzyskują z chwilą wpisu do Krajowego Rejestru Sądowego) i zwykłe (nieposiadające osobowości prawnej) (Ibidem, art. 9, 40). Stowarzyszenia realizujące postulaty Kościoła są stosunkowo licznie reprezentowane wśród grup interesu. Przykładem takiego podmiotu jest Katolickie Stowarzyszenie „Civitas Christiana” (KS „CC”). W 1993 r. na Nadzwyczajnym Walnym Zgromadzeniu Stowarzyszenia PAX w Częstochowie zebrani przekształcili je w „Civitas Christiana” (Petrowa-Wasilewicz, 2014, s. 249). W 1997 r. dekretem Przewodniczącego KEP organizacja została oficjalnie uznane przez władze kościelne jako stowarzyszenie katolickie. Zgodnie ze statutem, celem „Civitas Christiana” jest „kształtowanie rzeczywistości polskiej w oparciu o chrześcijańską koncepcję człowieka i świata, ujętą w nauczaniu Kościoła rzymskokatolickiego oraz zgodnie z polską tradycją narodową, a w szczególności: 1) ochrona życia i godności człowieka, rodziny, Narodu oraz troska o duchowe, moralne i materialne środowisko ich życia i rozwoju, 2) przygotowanie katolików świeckich do aktywnego i odpowiedzialnego uczestnictwa w życiu Kościoła, Narodu i Państwa, 3) kształtowanie i upowszechnianie chrześcijańskich, patriotycznych, demokratycznych i obywatelskich postaw oraz kryteriów oceny rzeczywistości kulturowej, społecznej, gospodarczej i politycznej" (Civitas). Członkowie stowarzyszenia uczestniczą np. w marszach życia, występują przeciwko określonym prawnym regulacjom in vitro.

Fundacje są organizacjami pozarządowymi tworzonymi dla celów społecznie lub gospodarczo użytecznych, zgodnie z podstawowymi interesami państwa. Fundatorami mogą być wszelkie osoby fizyczne, prawne. Fundacja posiada wyodrębniony majątek przeznaczony na określone cele społeczne. Fundacje są osobami prawnymi, osobowość prawną nabywają z chwilą wpisu do KRS (por. ustawa z dnia 6 kwietnia 1984 r...., art. 1-7), działają na podstawie określonego statutu. Są to organizacje nie nastawione na zysk, mogą prowadzić działalność gospodarczą. Utworzona w 1991 r. Fundacja „Głos dla Życia” podejmuje różne działania na rzecz obrony życia i rodziny. Główne obszary działalności fundacji to: pomoc materialna dla kobiet w ciąży, rodzin wielodzietnych; edukacja i wychowanie (wydawanie magazynu „Głos dla Życia”, kalendarza „Kocham Życie”, dystrybucja książek i materiałów podkreślających wartość życia ludzkiego, konieczność jego ochrony, organizacja konferencji, zjazdów, festynów dla rodzin, poradnictwo); aktywność na forum społeczno-politycznym (np. współorganizowanie Marszów Życia w Poznaniu, występowanie na forum parlamentu na rzecz zaostrzenia prawa antyaborcyjnego) (Gtos).

Federacje organizacji pozarządowych są reprezentacjami III sektora, budowane przez organizacje powiązane wokół konkretnego celu. Federacje są rzecznikami organizacji członkowskich, świadczą dla nich usługi, wyznaczają dla nich określone standardy działania (Federacja). Zasady powoływania i działania federacji zostały zawarte w prawie o stowarzyszeniach. Założycielem związku stowarzyszeń muszą być co najmniej trzy stowarzyszenia, mogą być nimi także inne osoby prawne (przy czym osoby prawne mające cele zarobkowe mogą być członkami wspierającymi) (Ustawa z dnia 7 kwietnia 1989 r...., art. 22). Przykładem takiego związku pro-life, niosącego pomoc kobietom w ciąży w trudnej sytuacji życiowej i rodzinom wielodzietnym jest Polska Federacja 
Ruchów Obrony Życia (PFROŻ), która powstała w 1992 r. W 2016 r. federacja skupiała 136 podmiotów, w tym 43 stowarzyszenia, 18 fundacji (w tym Fundacje „Głos dla Życia"), 10 instytucji, 48 ruchów i grup nieformalnych oraz 7 lokalnych porozumień na rzecz życia. Jednym z głównych celów ustawowych PFROŻ jest ,inspirowanie i popieranie wszelkich działań zmierzających do ukształtowania takiego systemu prawnego, który chroniłby życie i zdrowie dziecka poczętego i jego matki, także w sensie prawno-karnym" (Polska). Federacja wspiera w parlamencie projekty ustaw zmierzające do zaostrzenia obowiązującej ustawy aborcyjnej, sprzeciwia się wprowadzenia metody in vitro, legalizacji związków partnerskich.

Zgodnie z ustawą związki zawodowe to dobrowolne i samorządne organizacje ludzi pracy, powołane do obrony i reprezentowania ich praw, interesów zawodowych i socjalnych (Ustawa z dnia 23 maja 1991 r...., art. 1, ust. 1). Związki zawodowe odwołujące się w swoich założeniach ideowo-programowych do wartości chrześcijańskich, czy katolickich są często naturalnymi sojusznikami Kościoła. Do tej kategorii grup interesów można zaliczyć NSZZ „Solidarność”. W preambule statutu związu „Solidarność” wyraźnie stwierdza się, że związek opiera swoje działania na gruncie etyki chrześcijańskiej i katolickiej nauki społecznej (Jednolity). „Solidarność” wielokrotnie wspierała postulaty Kościoła np. w zakresie modelu stosunków wyznaniowych w trakcie prac nad konstytucją w latach 90. XX w., ustawodawstwa antyaborcyjnego, ustanowienia dodatkowych dni wolnych od pracy, zakazu handlu w niedzielę.

Do kategorii instytucje należą wyspecjalizowane podmioty powoływane przez KEP. Precyzyjną zatem nazwą dla ich określenia jest termin katolickie instytucje kościelne. Do tej grupy należy zaliczyć Krajową Radę Katolików Świeckich (KRKŚ), utworzoną w 1994 r., m.in. w celu pogłębiania formacji duchowej i intelektualnej katolików świeckich. W jej skład wchodzą przedstawiciele 14 metropolii (Krajowa). KRKŚ wystosowuje oświadczenia, apele, listy w istotnych dla Kościoła kwestiach.

Wymienionych powyżej pięć kategorii grup interesu można określić jako sformalizowane. Nie wszystkie grupy interesów artykułujące postulaty Kościoła posiadają osobowość prawną. W ujęciu socjologicznym ruch jest zbiorowym działaniem ukierunkowanym na szczególny cel, jakim jest zrealizowanie jakiegoś rodzaju zamiany społecznej; ma niezinstytucjonalizowany i niesfromalizowany charakter (Sztompka, 2007, s. 158). Katolickie ruchy religijne koncentrują się na formacji duchowej swoich członków. Do kategorii niesformalizowanych ruchów katolickich można zaliczyć Odnowę w Duchu Świętym (OwDŚ). Za początek OwDŚ uznaje się spotkanie modlitewne wykładowców i studentów w $1967 \mathrm{r}$. w Pittsburghu w USA. W Polsce pierwsze grupy Odnowy zaczęły powstawać w drugiej połowie lat 70. XX wieku. OwDŚ jest spontanicznym, oddolnym ruchem bez jednolitego kierownictwa, skupia się na spotkaniach modlitewnych (Katolicka, Petrowa-Wasilewicz, 2000, s. 27-30). Niemniej jednak jej członkowie wypowiadają się przeciwko aborcji.

Grupy wiernych mają charakter niesformalizowanych wspólnot, działających w poszczególnych parafiach. Przykładem niesformalizowanej grupy wiernych, zaangażowanych w działalność publiczna, jest działające w Szczecinie Bractwo Małych Stópek (BMS). Celem bractwa jest integracja obrońców życia, działających indywidualnie i w ruchach pro-life. Bractwo jest jednym z organizatorów Marszu dla Życia w mieście (Bractwo).

II. Kryterium członkostwa.

1) członkostwo pośrednie; 
2) członkostwo bezpośrednie:

a) grupy inkluzywne,

b) rupy ekskluzywne.

Grupy o członkostwie pośrednim to federacje różnego typu, skupiające organizacje pozarządowe (stowarzyszenia, fundacje), instytucje kościelne, grupy nieformalne; np. wspomniana PFROŻ. Osoby fizyczne są członkami poszczególnych podmiotów federacji. Grupy o członkostwie bezpośrednim skupiają bezpośrednio osoby fizyczne, spełniające określone kryteria statutowe, charakteryzują się otwartym lub zamkniętym typem przynależności personalnej.

Inkluzywne grupy interesu wyróżniają się otwartym charakterem członkostwa. W przypadku podmiotów wspierających postulaty Kościoła, jedynym kryterium przynależności do nich jest akceptacja deklarowanych celów, wartości (katolickich, chrześcijańskich, konserwatywnych). Do tej kategorii można zaliczyć Akcję Katolicką (AK), nawiązującą do organizacji działającej w Polsce przed II wojną światową. Została powołana w 1996 r. dekretem Prymasa Polski kard. Józefa Glempa (Petrowa-Wasilewicz, 2000, s. 237-239). Zgodnie ze statutem, celem Akcji ,jest pogłębianie formacji chrześcijańskiej oraz organizowanie bezpośredniej współpracy katolików świeckich z hierarchią kościelną w prowadzeniu misji apostolskiej Kościoła". AK realizuje swój cel m.in. przez „zajmowanie stanowiska w sprawach publicznych Kościoła, a zwłaszcza przez reagowanie na zagrożenia wiary i moralności chrześcijańskiej”. Członkiem organizacji może być każdy katolik świecki, który ukończył 18 rok życia $(A k c j a)$. Akcja wydaje oświadczenia, stanowiska, listy w istotnych sprawach światopoglądowych, społecznych, politycznych, np. przeciwko: liberalizacji ustawy antyaborcynej, ,,pigułce dzień po”, legalizacji związków homopar, wprowadzeniu regulacji i finansowaniu procedury in vitro, pracy w niedzielę, ,propagandzie gender”, ratyfikacji przez Polskę konwencji Rady Europy o zapobieganiu i zwalczaniu przemocy wśród kobiet i przemocy domowej; udziału w wyborach; czy propagowaniu określonych treści w mediach publicznych.

Grupy ekskluzywne skupiają członków według określonego kryterium społecznodemograficznego, zawodowego. W przypadku rozpatrywanych grup interesu, kluczowe kryteria socjo-demograficzne to: płeć i wiek. Przykładem takiej grupy jest Katolickie Stowarzyszenie Młodzieży (KSM), nawiązujące do tradycji przedwojennej. Stowarzyszenie zostało powołane dekretem KEP z 1990 r., zaś w 1993 r. konferencja zatwierdziła jego statut, w tym roku uzyskało osobowość prawną (Petrowa-Wasilewicz, 2000, s. 251-252). Celem stowarzyszenia ,jest kształtowanie dojrzałych chrześcijan oraz aktywne uczestnictwo we wspólnocie i misji Kościoła przez szerzenie i upowszechnianie katolickich wartości i zasad we wszystkich dziedzinach życia, zwłaszcza społecznego i kulturalnego". KSM zrzesza młodzież katolicką od 18 do 30 roku życia (Katolickie). Stowarzyszenie uczestniczy np. w akacjach antyaborcyjnych czy przeciw regulacji in vitro.

IV. Kryterium zasięgu terytorialnego.

1) międzynarodowe;

2) ogólnopolskie;

3) regionalne;

4) lokalne.

Do grup interesu, których działalność ma zasięg międzynarodowy należy Ruch „Światło - Życie” (RŚ-Ż). Ruch powstał z inicjatywy ks. Franciszka Blachnickiego w celu wychowa- 
nia dojrzałych chrześcijan. Na czele RŚ-Ż stoi moderator generalny (ksiądz), który kieruje nim przy pomocy Centralnej Diakonii Moderacji. W poszczególnych państwach za ruch odpowiedzialni są, będący księżmi, moderatorzy krajowi, w diecezjach - diecezjalni, w rejonach - rejonowi. RŚ-Ż działa poza Polską w Niemczech, Czechach i na Słowacji (PetrowaWasilewicz, 2002, s. 42-45; Ruch). RŚ-Ż ma przede wszystkim charakter formacyjny, ale zaznaczając swoją aktywność w sferze publicznej, występując np. przeciwko aborcji.

Natomiast do grupy interesu o zasięgu ogólnopolskim należą te z podmiotów, które swoim statutowym obszarem działania obejmują cały kraj. Wspomniana AK jest stowarzyszeniem ogólnopolskim o hierarchicznej strukturze. W parafii funkcjonują parafialne oddziały AK z zarządem parafialnym, komisją rewizyjna, parafialnym asystentem kościelnym; w diecezjach - diecezjalne instytuty AK (DIAK) z zarządem, radą DIAK, komisją rewizyjną DIAK, diecezjalnym asystentem kościelnym; na poziomie kraju - Krajowy Instytut AK (KIAK) z Zarządem, Radą, Komisją Rewizyjną KIAK, Biurem Krajowym i Krajowym Asystentem Kościelnym (Akcja).

Grupy o zasięgu regionalnym obejmują swoim obszarem działania obszar diecezji, województwa, kliku historycznych regionów, historycznego regionu lub subregionu. Do tej kategorii należą podmioty, które: 1) mają statutowo określony regionalnie obszar działania; 2) są oddziałami grup ogólnopolskich. Do pierwszej kategorii należy np. Stowarzyszenie Rodzin Katolickich Archidiecezji Przemyskiej, którego obszarem działania jest archidiecezja przemyska (przy czym dla celów statutowych może ono prowadzić działalność na trenie całej RP) (Stowarzyszenie). Do drugiej kategorii można zaliczyć np.: DIAK, regiony NSZZ „Solidarność”.

Grupy o zasięgu lokalnym obejmują swym obszarem działania obszar parafii, gminy, powiatu. Do tej kategorii należą przede wszystkim nieformalne grupy wiernych.

V. Kryterium celów.

1) grupy jednopunktowe;

2) grupy podejmujące różne kwestie problemowe.

Niesformalizowane i sformalizowane tzw. organizacje-promotor, określane też jako grupy jednopunktowe (single-issue), wypowiadają się w ściśle określonej kwestii. Szczególne znaczenie od lat 70. XX w. mają ruchy obrońców życia (pro-life), występujące przeciw finansowaniu zabiegów usuwania ciąży z funduszy publicznych, liberalizacji ustawodawstwa antyaborcyjnego oraz za umieszczeniem w konstytucji zapisów o ochronie życia poczętego (Roskin, Cord, Medeiros, Jones, 2001, s. 247-248). Przykładami grupy jednopunktowej jest powołane w 2005 r. stowarzyszenie - Fundacja Pro Prawo do Życia. Jednym z kluczowych jej celów statutowych jest „,wspomaganie działań mających na celu ochronę życia ludzkiego od momentu poczęcia do naturalnej śmierci, zdrową i udaną prokreację, przeciwdziałanie zapaści demograficznej" (Fundacja). Stowarzyszenie organizuje pikiety przed klinikami dokonującymi aborcji, uliczną wystawę antyaborcyjną. W 2011 i 2016 r. członkowie organizacji zbierali podpisy pod obywatelskim projektem nowelizacji ustawy antyaborcyjnej z 1993 r. Projekty trafily do Sejmu, lecz zostały odrzucone.

Do grup podejmujących różne kwestie problemowe należą np. AK, KS „CC”. Artykułują one postulaty Kościoła w różnych obszarach problemowych.

V. Kryterium związku z Kościołem katolickim.

1) grupy pozakościelne;

2) grupy kościelne. 
Przez pojęcie grupy pozakościelne należy rozumieć podmioty działające poza strukturami Kościoła katolickiego. W przypadku grup interesu artykułujących postulaty Kościoła katolickiego są to organizacje pozarządowe sensu stricte - stowarzyszenia i fundacje i sensu largo - związki zawodowe oraz nieformalne zrzeszenia osób. Przykładem tego typu grupy jest Fundacja Instytut na Rzecz Kultury Prawnej Ordo Iuris. Fundacja założona w 2013 r., skupia konserwatywnych prawników zaangażowanych „,w obronę ładu konstytucyjnego i jego aksjologicznej tożsamości poświadczonej w preambule do Konstytucji” (Ordo). Prawnicy Ordo Iuris sporządzili krytyczne analizy dotyczące m.in. ustaw o: związkach partnerskich, legalizacji zapłodnienia in vitro, uzgodnieniu płci, edukacji seksualnej, Konwencji Rady Europy o zapobieganiu przemocy wobec kobiet i przemocy domowej; przygotowali Projekt Inicjatywy Obywatelskiej „Stop Aborcji”; podejmują interwencje prawne $\mathrm{w}$ obronie działaczy pro life.

Tabela 2

Typologia grup interesu realizujących postulaty Kościoła katolickiego w Polsce

\begin{tabular}{|c|c|c|c|}
\hline Kryterium podziału & $\begin{array}{l}\text { Typ grupy } \\
\end{array}$ & Podtyp grupy & Przykład grupy \\
\hline \multirow[t]{7}{*}{ Organizacyjno-formalne } & Stowarzyszenia & - & $\mathrm{KS}, \mathrm{CC} "$ \\
\hline & Fundacje & - & „,Głos dla Życia” \\
\hline & Federacje organizacji pozarządowych & - & PFROŻ \\
\hline & Instytucje & - & KRKŚ \\
\hline & Związki zawodowe & - & NSZZ ,S” \\
\hline & \multirow{2}{*}{$\begin{array}{l}\text { Podmioty } \\
\text { niesformalizowane }\end{array}$} & Ruchy religijne & OwDŚ \\
\hline & & Grupy wiernych & BMS \\
\hline \multirow[t]{3}{*}{ Członkostwo } & Pośrednie & - & PFROŻ \\
\hline & \multirow[t]{2}{*}{ Bezpośrednie } & Inkluzywne & $\mathrm{AK}$ \\
\hline & & Ekskluzywne & KSM \\
\hline \multirow[t]{4}{*}{ Zasięg terytorialny } & Międzynarodowe & - & RŚ-Ż \\
\hline & Ogólnopolskie & - & $\mathrm{AK}$ \\
\hline & Regionalne & - & DIAK \\
\hline & Lokalne & - & BMS \\
\hline \multirow[t]{2}{*}{ Cel } & Jednopunktowe & - & Prawo do Życia \\
\hline & Podejmujące różne kwestie & - & AK \\
\hline \multirow[t]{2}{*}{ Związek z Kościołem } & Pozakościelne & - & Ordo Juris \\
\hline & Kościelne & - & KSM \\
\hline
\end{tabular}

Wykaz skrótów: KS „CC” - Katolickie Stowarzyszenie „Civitas Christiana”, „Głos dla Życia” - Fundacja „Głos dla Życia”, PFROŻ - Polska Federacja Ruchów Obrony Życia, KRKŚ - Krajowa Rada Katolików Świeckich, NSZZ „S” - Niezależny Samorządny Związek Zawodowy „Solidarność”, OwDŚ - Odnowa w Duchu Świętym, BMS - Bractwo Małych Stópek, AK - Akcja Katolicka, KSM - Katolickie Stowarzyszenie Młodzieży, RŚ-Ż - Ruch Światło-Życie, DIAK - Diecezjalny Instytut Akcji Katolickiej, Prawo do Życia - Fundacja Pro Prawo do Życia, Ordo Iuris - Fundacja Instytut na Rzecz Kultury Prawnej.

Źródło: Opracowanie własne.

Przez grupy kościelne należy rozumieć podmioty działające w strukturach Kościoła. Do tej kategorii będą należały katolickie organizacje pozarządowe ${ }^{3}$, instytucje Kościoła,

${ }^{3}$ Zgodnie z Kodeksem Prawa Kanonicznego stowarzyszenie może przybrać nazwę „katolickie” tylko za zgodą kompetentnej władzy kościelnej. Stowarzyszenia dzielą się na: publiczne stowarzyszenia świeckich i stowarzyszenia prywatne. Władzą kompetentną do erygowania publicznych stowarzyszeń wiernych jest: a. dla stowarzyszeń powszechnych lub międzynarodowych - Stolica Apostolska, 
ruchy religijne, grupy wiernych. Do tej kategorii można zaliczyć przykładowo wspomniane: KS ,CC”, KRKŚ, RŚ-Ż, BMS.

\section{Podsumowanie}

Kościół katolicki w Polsce oddziałuje na system polityczny i jego otocznie bezpośrednio lub pośrednio, m.in. poprzez określone grupy interesu. Są one naturalnymi sojusznikami Kościoła w zakresie oddziaływania na sferę polityki i przyjęcie określonych, korzystnych dla niego regulacji prawnych. „Kościelne” grupy interesu charakteryzują się dużym zróżnicowaniem, biorąc pod uwagę kryteria: organizacyjno-formalne (grupy sformalizowane i nieformalne), członkostwa (grupy z członkostwem pośrednim i bezpośrednim), zasięgu terytorialnego (od międzynarodowego po lokalny), celów (jeden lub kilka), związku z Kościołem (podległe hierarchii kościelnej lub nie). Przedstawiona typologia może stanowić asumpt do dalszych badań nad rolą i wpływem tego typu podmiotów na system polityczny Polski.

\section{Bibliografia}

\section{Ustawodawstwo państwowe i kościelne:}

Ustawa z dnia 6 kwietnia 1984 r. o fundacjach, Dz. U., 1984, Nr 21, poz. 97 z późn. zm.

Ustawa z dnia 7 kwietnia 1989 r. prawo o stowarzyszeniach, art. 2, ust. 1, Dz. U. 1989, Nr 29, poz. 104 z późn. $z m$.

Ustawa z dnia 23 maja 1991 r. o zwiqzkach zawodowych, Dz. U. 1991, Nr 55, poz. 234 z późn. zm.

Kodeks Prawa Kanonicznego 1983, http://katolicki.net/ftp/kodeks_prawa_kanonicznego.pdf, luty 2017.

\section{Monografie i artykuly:}

Braun-Poppelaars C., Hannegraaff M. (2011), Conceptualizing religious advocacy: religious interest groups and the process of public policy making, w: Religious Actors in the Public Sphere, red. J. Haynes, A. Hennig, Routledge, London-New York.

Delong M. (2016), Konferencja Episkopatu Polski wobec wybranych kwestii politycznych i społecznych w Polsce w latach 1989-2014, Wydawnictwo Uniwersytetu Rzeszowskiego, Rzeszów.

Enyedi Z. (2003), Conclusion: Emerging Issues in the Study of Church-State Relations, „West European Politics", vol. 26, issue 1.

Herzke A. D. (2012), Lobbing for the Faithful: Religious Advocacy Groups in Washington, D.C., Pew Research Center, Washington.

Knutson K. (2015), Interfaith Advocacy Groups in American Politics, w: The Changing Word Religion Map. Sacred Places, Identities, Practices and Politics, red. S. D. Brunn, Springer Netherlands, Dordecht.

b. dla stowarzyszeń krajowych - KEP, c. dla stowarzyszeń diecezjalnych - biskup diecezjalny. Stowarzyszenia prywatne to ruchy i wspólnoty powstałe z inicjatywy wiernych, w których zrzeszają się oni na podstawie umowy prawnej. Posiadają one większą autonomię, ale też muszą ubiegać się o zatwierdzenie władz kościelnych. Kodeks Prawa Kanonicznego 1983, kan. 298-329, http://www.katolicki.net/ ftp/kodeks_prawa_kanonicznego.pdf, odczyt z dn. 12.02.2017. 
Kowalczyk K. (2016), Między antyklerykalizmem a konfesjonalizacją. Partie polityczne wobec Kościoła katolickiego w Polsce po 1989 roku, MADO, Torun.

Lipiński A. (2016), Prawica na polskiej scenie politycznej w latach 1989-2011. Historia, organizacja, tożsamość, Dom Wydawniczy ELIPSA, Warszawa.

Oświecimski K. (2012), Grupy interesu i lobbing w amerykańskim systemie politycznym, Wydawnictwo WAM, Kraków.

Petrowa-Wasilewicz A. (2000), Leksykon ruchów i stowarzyszeń w Kościele, Katolicka Agencja Informacyjna, Warszawa.

Potz M. (2016), Empowerment trough religion: religion's survival strategies in democratic politics, „Przegląd Politologiczny”, nr 4.

Roskin M. G, Cord R. L., Medeiros J. A., Jones W. S. (2001), Wprowadzenie do nauk politycznych, Zysk i S-ka, Poznań.

Sztompka P. (2007), Socjologia, ZNAK, Kraków.

\section{Strony internetowe:}

Akcja Katolicka, http://ak.org.pl, luty 2017.

Bractwo Małych Stópek, http://dlazycia.info, luty 2017.

Civitas Christiana, http://civitaschristiana.pl, luty 2017.

Federacja, http://poradnik.ngo.pl/federacja, luty 2017.

Fundacja Pro - Prawo do Życia, http://stopaborcji.pl, luty 2017.

Głos dla Życia, http://glosdlazycia.pl, luty 2017.

Jednolity tekst statutu NSZZ ,Solidarnośc”" po wprowadzeniu zmian uchwalonych przez XXVII Krajowy Zjazd Delegatów NSZZ ,,Solidarność” w dniach 8-9 października 2014 r., http://solidarnosc.org.pl/images/files/dokumenty/statut/Statut_2014_po_zmianach.pdf, luty 2017.

Katolicka Odnowa w Duchu Świętym, http://odnowa.org, luty 2017.

Katolickie Stowarzyszenie Młodzieży, http://ksm.org.pl, luty 2017.

Krajowa Rada Katolików Świeckich, http://katolicy-swieccy.pl, luty 2017.

Ordo Iuris, http://www.ordoiuris.pl, luty 2017.

Polska Federacja Ruchów Obrony Życia, http://federacjazycia.pl, luty 2017.

Ruch Światto-Życie, http://oaza.pl, luty 2017.

Stowarzyszenie Rodzin Katolickich Archidiecezji Przemyskiej, http://dlarodziny.przemyska.pl, luty 2017.

\section{Typology of interest groups divide the postulates of the Catholic Church in Poland}

\section{Summary}

The aim of the article is to classify interest groups divide the postulates of the Catholic Church in Poland. Accordingly, the Church was defined in terms of political science, the forms of the Church's influence on the political system were defined, the concept of interest groups was defined in relation to the analyzed subject, and then based on specific criteria they were typified. The proposed typology may be the starting point for further research in this field.

Key words: Catholic Church in Poland, political system, interest groups 